\title{
An Assessment of Inspectors' Compliance with Inspection Principles in Public Secondary Schools in Nigeria
}

\author{
*Bamire F. B., T. L. Adepoju \\ Obafemi Awolowo University, Ile-Ife, Nigeria \\ *asbamire@yahoo.co.uk
}

\begin{abstract}
Public secondary school education is rapidly growing in Nigeria, requiring huge investments by government. To justify the level of investments and improve the quality of education in the secondary schools, there is need for proper monitoring and evaluation through inspection. This paper examines the extent to which inspectors complied with inspection principles of independence, impartiality, transparency and mutual respect in public secondary schools in Ekiti state, Nigeria. This is with the view to improving the quality of education in the state. A multi-stage sampling technique was used to select 147 respondents, comprising 120 teachers, 12 principals, and 15 inspectors. Data were collected using survey questionnaires complemented with interview guide. Data were analysed with the use of frequency counts, percentage and means. Results showed that $46.7 \%$ of the inspectors indicated compliance with the inspection principles of independence, 40\% with impartiality and transparency, and 53.3\% with mutual respect. On the average, about $47 \%$ of the inspectors indicated compliance with all the inspection principles. The study concluded that inspectors' compliance with inspection principles is low and therefore, intensifying their compliance with inspection principles is imperative to improving the standard of education in public secondary schools.
\end{abstract}

Keywords: Inspectors, Inspection, Principles, Compliance, Public Secondary Schools

\section{Introduction}

School inspection aims at quality control in education and it is regarded as one of the functions of the inspectorate division of the Ministry of Education. Inspection has been defined as the process of assessing the quality and or performance of institutions, services, programs, and projects, by those (inspectors) who are not directly involved in them and who are specially appointed to fulfil these responsibilities (Wilcox, 2000). Arising from this definition is school inspection, defined as the critical examination and the subsequent evaluation of a school as a designated place of learning so as to make it possible for the necessary advice to be given for the purpose of improving the school. Thus, through inspection, the school system is reshaped to enhance the standard of education (Kpolovie, Ololube \& Ekwebelem, 2011). Schools are required to be inspected by inspectors (i.e. the officials of the Inspectorate Department of the Ministry of Education) at prescribed intervals and to report on: (a) the quality of the education provided in the school, (b) how far the education meets the needs of the range of students at the school, (c) the educational standards achieved in the school, (d) the quality of leadership and management of the school, (e) the spiritual, moral, social and cultural development of the students at the school, and (f) the contribution made by the school to the well-being of students. The inspectors visit schools to ascertain that set educational standards are being maintained and to guide, assist as well as give advice to school staff on how best to improve the quality of instruction for the purpose of improving school outcomes like students' academic performance (e.g., Ochuba, 2010). The inspectors also examine every aspect of the school setting including physical facilities, equipment, the administration and organization of the school, students' books, teachers' schemes, notes of lesson, records of work, and discipline.

An effective inspectorate service is therefore expected to improve teachers' competence and standard of instructions in schools (e.g., Onyidoh, 2007). However, different challenges are faced by the inspectorate services in carrying out their roles efficiently. These challenges include inadequacy of facilities, inadequate number of inspectors and lack of training opportunities. Some studies have attributed these challenges to the non-adherence of inspectors to inspection principles which are rules and guidelines of the activities and operations of school inspectors in the discharge of their duties in ensuring outcomes in terms of academic performance (e.g., Ochuba, 2010). For example, the gradual decline in quality of education offered in schools is evidenced by the poor performance of students in public examinations such as WAEC and NECO SSCE (e.g., FME, 2006; Onyidoh, 2007; Ochuba, 2010). Reporting on the 
educational standard of Ekiti state, (Alade, 2008) showed that Ekiti ranked 36 th position out of the 36 states of the Federation and the Federal Capital Territory, Abuja in WASSCE and NECO SSCE between 1999 and 2003.

To provide insight into the challenges facing the inspectorate division towards ensuring quality in the public secondary schools, it is imperative to conduct an in-depth study of inspection principles namely: independence, impartiality, transparency and mutual respect. It will also assist the educational policy makers to formulate appropriate policies for more effective inspection framework in public secondary schools and in raising the educational standard. This paper therefore investigates the extent to which inspectors comply with specific inspection principles such as independence, impartiality, transparency and mutual respect in public secondary schools in Ekiti State, Nigeria. This is with the view to improving the performance of students in public examinations and educational development in the state.The specific objectives are to (i) examine the extent to which inspectors comply with inspection principle of independence in public secondary schools in the study area; (ii) assess inspectors' level of compliance with the inspection principle of impartiality; (iii) analyse the degree to which inspectors comply with the inspection principle of transparency; and (iv) examine the extent to which inspectors comply with inspection principle of mutual respect in the study area. The main research question of this paper is: To what extent do inspectors comply with inspection principles (independence, impartiality, transparency and mutual respect) in public secondary schools in Ekiti state, Nigeria?

\section{Methodology}

The survey research design was used in the study. The population of the study consisted of all the principals and teachers in Ekiti state public secondary schools, as well as the inspectors at the Inspectorate Department of the State's Ministry of Education (Sis) comprising Tutor-Generals (TGs), Local Inspectors of Education (LIEs) and Area Education Officers (AEOs) in the state. Variables of inspection principles analysed include independence, impartiality, transparency and mutual respect (e.g., Ochuba, 2010). The sample was made up of 147 respondents, comprising 120 teachers, 12 principals and 15 inspectors. Based on the number of the Local Government areas (LGAs), three out of 16 LGAs in Ekiti (representing $18.8 \%$ of the total number of LGAs in the state) were selected randomly. From each LGA, four schools $(20 \%$ of the total number of schools in the LGAs) were selected randomly to give a total of 12 schools. In each school, 10 teachers $(50 \%$ of the total number of teachers) who have spent at least five sessions in the senior secondary (SS) schools were purposively selected making a total of 120 teachers. All the principals in the 12 selected schools were involved. In each of the Inspectorate services of the state's Ministry of Education, five Inspectors of Education (20\% of the total number of inspectors in the state) were randomly selected. At the LGA level, the Local Inspectors of Education in each of the 3 selected LGAs were involved while two AEO representing 50\% of AEOs in the LGAs who have served for at least five years in the LGA were purposively selected in each of the LGAs to give a total of 6 AEOs. One of the Tutor-Generals in the state was also involved. The sampling procedure is as presented in Table 1 (e.g., Nworgu, 2006).

Table 1: Sampling procedure for the selection of respondents in Ekiti State

\begin{tabular}{|c|c|c|c|c|c|c|c|c|c|c|}
\hline \multirow{2}{*}{$\begin{array}{l}\text { Total } \\
\text { LGAs } \\
\text { (No.) }\end{array}$} & \multirow{2}{*}{$\begin{array}{l}\text { LGAs } \\
\text { (No.) }\end{array}$} & \multirow{2}{*}{$\begin{array}{l}\text { Schools } \\
\text { (No.) }\end{array}$} & \multirow{2}{*}{$\begin{array}{l}\text { Principal } \\
\text { s (No.) }\end{array}$} & \multirow{2}{*}{$\begin{array}{l}\text { Teachers } \\
\text { (No) }\end{array}$} & \multicolumn{6}{|c|}{ No. of Inspectors } \\
\hline & & & & & SIs & TGs & LIE & $\begin{array}{l}\mathrm{AE} \\
\mathrm{Os}\end{array}$ & $\begin{array}{l}\text { Total } \\
\text { Inspect } \\
\text { ors }\end{array}$ & $\begin{array}{l}\text { Total } \\
\text { Respond } \\
\text { ents }\end{array}$ \\
\hline 16 & 3 & 12 & 12 & 120 & 5 & 1 & 3 & 6 & 15 & 147 \\
\hline
\end{tabular}

Source: Author's design, 2012.

Data collection methods: Both survey questionnaire and in-depth interview guide were used to collect data for this study. The in-depth interview guide was used to collect information on inspectors. Three sets of questionnaire were used for the study. The questionnaires contained information on inspectors and the level of their compliance with respect to the principles of independence, impartiality, transparency, and mutual respect. These questionnaires were complemented with interview guide that contained questions on inspectors' job performance and their challenges in the Ministry and schools.

Validity and Reliability of Instruments: The quality of the measuring instruments is determined by their validity and reliability.The content and face validity of the questionnaire were carried out by experts 
in educational administration, inspectorate division as well as test and measurements department. This was used to measure how adequately the instruments covered the variables of the study, and to know whether the research instruments measured or addressed the required information within the framework of the research objectives. The experts' judgement revealed that the instrument had adequate content and face validity. Similarly, the reliability of the research instrument is determined by the extent to which the instrument yields the same results on repeated trials based on the pilot study. Cronbach's alpha was used to provide the internal consistency reliability estimate of the instruments. The instruments were subjected to reliability analysis and the alpha values were obtained using the correlation matrix (e.g., Gleim \& Gleim, 2003):

Alpha $=\mathrm{Np} /[1+\mathrm{p}(\mathrm{N}-1)]$

Where $\mathrm{N}$ equals the number of items and $\mathrm{p}$ equals the mean inter-item correlation.

The reliability coefficients obtained for the three instruments were $0.82,0.85$, and 0.78 respectively. The values obtained were greater than 0.5 , implying that the questionnaires were reliable. The instruments were administered on the respondents (inspectors, principals and teachers) of the sampled schools and inspectorate services. The entire questionnaire could not be retrieved because of the inadequate number of inspectors in the area offices of the Inspectorate Department. While $100 \%$ of the copies of questionnaire administered on the principals were retrieved, 12 out of $15(80 \%)$ copies administered on inspectors and $94.2 \%$ copies administered on the teachers were retrieved. In-depth interviews were also conducted on inspectors from the ministry and area offices of the inspectorate department of the Ministry of Education in Ekiti state. Data generated from the questionnaires were analysed using the Statistical Package for Social Sciences (SPSS) version 16.0 (Gujarati, 2006). Based on the research questions raised, descriptive statistics comprising frequencies, percentages, and means were used to answer the research questions. Data collected with the questionnaires were tabulated, classified and organized along the modified Likert-type opinion/attitude scale originally devised by Rensis Likert (Nworgu, 2006). This was on a four-point scale running from 1 to 4 , with a high score denoting high effectiveness. That is, Strongly Disagree (SD), 1; Disagree (D), 2; Agree (A), 3 and strongly Agree (SA) was scored 4 (Likert, 1932, \& Asika, 1991).

\section{Results}

In answering the research question:"To what extent do inspectors comply with inspection principles (impartiality, independence, transparency and mutual respect) in public secondary schools in Ekiti State?", the inspection principles identified in the questionnaire were sorted and classified into categories of impartiality, independence, transparency and mutual respect for ease of presentation. Inspectors' responses to the questionnaire were scored based on the 4- point Likert scale and this was used to categorize inspectors' compliance with inspection principles of impartiality, independence, transparency and mutual respect.

Table 2 shows the extent of inspectors' compliance with inspection principles of impartiality, independence, mutual respect and transparency. Principals and teachers' perception in the public secondary schools in Ekiti state are also presented. From Table 2, inspectors' compliance with the principle of impartiality showed that $60 \%$ of the inspectors corrected teachers for poor job performance. This view was supported by $91.7 \%$ and $83.3 \%$ of the principals and teachers respectively, suggesting that inspectors complied with this item of the principle of impartiality in the secondary schools. About $47 \%$ inspectors maintained an objective stance and checked evidence before evaluationas supported by $67 \%$ principals and $61 \%$ teachers. However, a smaller percentage of the inspectors $(13.3 \%)$ provided unbiased and professional evaluation of educational facilities in the schools as supported by $25 \%$ and $21 \%$ of the principals and teachers respectively. This shows that inspectors complied with two out of the three items of the principle of impartiality considered in this study. Nonetheless, on the average, $40 \%$ inspectors indicated compliance with the principle of impartialityas supported by $66.7 \%$ of the principals and $55 \%$ teachers. This implies that in general, inspectors complied with the principle of impartiality in the schools. Inspectors' compliance with the principle of independence showed that $33.3 \%$ inspectors worked without interference by principals and teachers in the schools. This view was supported by only about $42 \%$ and $3 \%$ of the principals and teachers respectively. Less than half of the inspectors $(46.7 \%)$ listened carefully to principals'views but based their judgements on their professionalism, as agreed by $58.3 \%$ of the principals and $27.5 \%$ teachers. Also, $60 \%$ of the inspectors ensured an independent focus on raising educational standard in schools, as corroborated by about $67 \%$ and $55 \%$ principals and teachers respectively.On the average, about $47 \%$ inspectors indicated compliance with the principle of 
independence as supported by $58 \%$ and $15 \%$ of the principals and teachers respectively. This suggests that only principals agreed to an extent that inspectors complied with the principle of independence in the schools, while most teachers were not in support.

Table 2: Inspectors' compliance with inspection principles and principals and teachers' perception in public secondary schoolsin Ekiti state.

\begin{tabular}{|c|c|c|c|}
\hline Inspection Principles & $\begin{array}{l}\text { Inspectors } \\
(n=15)\end{array}$ & $\begin{array}{l}\text { Principals } \\
(n=12)\end{array}$ & $\begin{array}{l}\text { Teachers } \\
(n=120)\end{array}$ \\
\hline Impartiality & $6(40.0)$ & $8(66.7)$ & $66(55.0)$ \\
\hline Inspector corrects teachers when job is not well done & $9(60.0)$ & $11(91.7)$ & $100(83.3)$ \\
\hline $\begin{array}{l}\text { Inspectors maintain an objective stance and check } \\
\text { evidence before evaluating }\end{array}$ & $7(46.7)$ & $8(66.7)$ & $73(60.8)$ \\
\hline $\begin{array}{l}\text { Inspectors provide unbiased and professional evaluation } \\
\text { of the quality of educational provisions in the school }\end{array}$ & $2(13.3)$ & $3(25.0)$ & $25(20.8)$ \\
\hline Independence & $7(46.7)$ & $7(58.3)$ & $18(15.0)$ \\
\hline $\begin{array}{l}\text { Inspectors are allowed to work without interference by } \\
\text { the principal and teachers }\end{array}$ & $5(33.3)$ & $5(41.7)$ & $3(2.5)$ \\
\hline $\begin{array}{l}\text { Inspectors listen carefully to the views of the principals } \\
\text { but base their judgements on their professionalism }\end{array}$ & $7(46.7)$ & $7(58.3)$ & $33(27.5)$ \\
\hline $\begin{array}{l}\text { Inspectors ensure an independent focus on raising } \\
\text { educational standard }\end{array}$ & $9(60.0)$ & $8(66.7)$ & $17(14.2)$ \\
\hline Mutual Respect & $8(53.3)$ & $9(75.0)$ & $75(62.5)$ \\
\hline Inspectors have good relationship with principal & $11(73.3)$ & $11(91.7)$ & $98(81.7)$ \\
\hline Inspectors have good relationship with teachers & $10(66.7)$ & $11(91.7)$ & $90(75.0)$ \\
\hline $\begin{array}{l}\text { Inspectors motivate teachers by commending them when } \\
\text { job is well done }\end{array}$ & $4(26.7)$ & $6(50.0)$ & $55(45.8)$ \\
\hline $\begin{array}{l}\text { Inspectors have mutual respect for the principal and } \\
\text { teachers while carrying out their duty }\end{array}$ & $7(46.7)$ & $8(66.7)$ & $58(48.3)$ \\
\hline Transparency & $6(40.0)$ & $7(58.3)$ & $49(40.8)$ \\
\hline $\begin{array}{l}\text { Inspectors provide feedback to teachers after classroom } \\
\text { monitoring and evaluation }\end{array}$ & $7(46.7)$ & $9(75.0)$ & $84(70.0)$ \\
\hline Inspectors involve staff being inspected appropriately & $6(40.0)$ & $8(66.7)$ & $73(60.8)$ \\
\hline Inspectors provide feedback to the school & $5(33.3)$ & $6(50.0)$ & $15(12.5)$ \\
\hline $\begin{array}{l}\text { Inspectors are open, provide their perspective and share } \\
\text { findings with principal/teachers during inspection }\end{array}$ & $9(60.0)$ & $4(33.3)$ & $24(20.0)$ \\
\hline Average (\%) & 46.7 & 64.6 & 43.3 \\
\hline
\end{tabular}

* Figures in parentheses ( ) are percentages; $\mathrm{n}=$ number of respondents

Inspectors' compliance with the principle of mutual respect showed that $73.3 \%$ of the inspectors had good relationship with principals as supported by about $92 \%$ and $82 \%$ of principals and teachers respectively. About $67 \%$ of the inspectors had good relationship with teachers, as agreed to by $92 \%$ of principals and $75 \%$ teachers. Less than $50 \%$ of the inspectors (about $27 \%$ ) agreed that they motivated teachers by commending them for good job performance, as corroborated by $50 \%$ and $45.8 \%$ of the principals and teachers respectively. In addition, about $47 \%$ of the inspectors agreed that they showed mutual respect for the principals and teachers in the schools while carrying out their duties. This is supported by about $67 \%$ and $48 \%$ of principals and teachers respectively. The extent of inspectors' compliance with the principle of mutual respect showed that $53.3 \%$ inspectors indicated compliance while $75 \%$ principals and $62.5 \%$ teachers supported their claim. This implies that inspectors complied with the principle of mutual respect in the secondary schools. Inspectors' compliance with the principle of transparency showed that $46.7 \%$ of inspectors provided feedback to teachers after classroom monitoring and evaluation; as supported by $75 \%$ principals and $70 \%$ teachers. Forty percent inspectors involved staff being inspected appropriately during inspection, as supported by about $67 \%$ principals and $61 \%$ teachers. About $33 \%$ of the inspectors provided feedback to schools after inspection, while $50 \%$ and $12.5 \%$ principals and teachers respectively supported the inspectors' claim. Also, 60\% inspectors demonstrated openness in providing their perspective and sharing their findings with principals and teachers during inspection. However, only $33.3 \%$ principals and $20 \%$ teachers agreed to the inspectors' claim. On the average, $40 \%$ of the Inspectors complied with the principle of transparency. 
On the average, about $47 \%$ of the inspectors indicated compliance with all the inspection principles as supported by $64.6 \%$ principals and $43.3 \%$ teachers. This implies that inspectors' compliance with inspection principles was generally low in the public secondary schools in Ekiti State. The extracts of the report of in-depth interview with inspectors in the Ministry of Education in Ekiti state is presented in Table 3. It was found that inspectors in the inspectorate department of the Ministry of education in the state always make necessary preparations before setting out for inspection exercises in the schools. Operational inspection (also known as routine inspection in other states in South-western Nigeria) is the most common inspection exercise conducted in the schools. At every instance of the inspection exercise, the inspectors were treated well even though they do not make specific demands for this. Lateness to school by teachers and students as well as problems of infrastructure pose great challenges in school inspection.

Table 3: Report of in-depth interview with inspectorsin Ekiti state

Item
What preparations are usually put
in place before embarking on
inspection exercise?
Which is the commonest
inspection exercise conducted by
the inspectorate division and for
what purpose?
How does the school take care of
inspectors? the challenges
What are the
associated with inspection
exercise in schools?
How do inspectors address the
challenges identified in schools
during inspection

What are the challenges facing the inspectorate division?

Does the Ministry of Education respond to inspection reports on schools?

\section{Inspectors}

We have a template on how to conduct inspection which is contained in a proforma. We assemble the inspection team and teach them how to comport themselves when in the school.

The commonest is operational inspection. It is for monitoring teachers' effective delivery of their duty.

They do not have to take care of the inspectors but at times they give us drinks, but this is not compulsory.

Teachers' lateness to school; teachers' on maternity leave; extracurricular activities in the school. All these prevent teachers presence in the class at all times.

Teachers are warned to desist from coming late to school and schools are advised on the amount of extra-curricular activities they need. Problems on infrastructure are reported to the appropriate quarters (the permanent secretary in the Ministry) because it requires some bureaucracies.

Inadequate number of personnel, finance, inadequate facilities such as transport, stationery, computer, generator, and inadequate training opportunities.

The Ministry does give response but this may not get to the school on time because of the bureaucracy in the Ministry.

Discussion of Findings: School inspection is one of the strategies for monitoring teaching learning process in Ekiti state public secondary schools. Inspectors' adherence to inspection principles of independency, impartiality, transparency and mutual respect is capable of enhancing quality and raising students' academic performance in schools. The average of $40 \%$ recorded on Inspectors' compliance with the principle of impartiality shows that inspectors' unbiased and professional evaluation of the quality of educational provisions in the schools was not too satisfactory. There is therefore a need to train and guide the inspectors to adhering strictly to this principle. This implies that inspectors require continuous training in understanding the fundamental principles guiding their inspection processes and practices (e.g., Ogunu, 2002; Marshal, 2008). Similarly, Inspectors' compliance with the principle of transparency that averaged $40 \%$ shows that most Inspectors were not carrying out their jobs within the framework of this principle. In other words, openness about the inspection processes and involvement of staff being inspected appropriately in the inspection process in schools was poor. This agrees with the findings (e.g., Bamisaye, 1998; Adelabu, 2003; Alade, 2008) that the attitude of inspectors towards teachers in supervising their work is an important work-related motivational factor. About $47 \%$ of the Inspectors indicated compliance with the principle of independence. This suggests that the staff in the schools (principals and teachers) do interfere with Inspectors' judgments after listening carefully to the views of staff being inspected in the schools. This corroborates the findings (e.g., Dean, 1995; Abolade, 2007; Ochuba, 2010) who emphasized the importance of giving feedback to school as teachers get frustrated if they do not receive feedback reports from the inspection exercise. Thus, any attempt made to intensify inspectors' compliance with the inspection principles of transparency and independence is capable of improving the standard of education in the public secondary schools. 
The average of 53.3\% reported for Inspectors' compliance with the principle of mutual respect shows that inspectors have a good relationship with principals and teachers during inspection exercises. This negates the findings of Maranga (1986) \& Obilade (1992) that there was no cordial relationship, trust and open communication between inspectors and the teachers in schools. Specifically (e.g., Dean, 1995) found that teachers generally felt threatened by the intimidating attitude of inspectors and this affected their job performance in the schools. However, the findings in this study may not be surprising in that some of the Local Inspectorate of Education Offices in Ekiti state is situated within the premises of the schools. The overall average of about $47 \%$ of the inspectors that indicated compliance with all the inspection principles suggests that inspectors' compliance with the inspection principles was below average. This means that there is still a large room for improvement (a margin of 53\%), and efforts need be intensified to enable inspectors comply fully with all the inspection principles. This is consistent with the findings of Ochuba (2010) that one of the factors affecting academic quality in public secondary schools was inadequate application of inspection principles. It is also important to note that all the components of inspection principles are important for consideration in any strategy aimed at ensuring quality education in public secondary schools in Ekiti State. Therefore any attempt made to ensure inspectors' compliance with these inspection principles by the inspectorate services would improve students' academic performance and raise the standard of education in the state. This is consistent with the findings of Aghenta (2006) that regular inspection of schools has the potential of promoting school outcomes students' academic performance.Government should also implement the recommendation from inspection reports as corroborated by the findings of Onasanya (2007) that educational activities need supervision and inspection to achieve educational objectives.

\section{Conclusion}

The study concluded that school inspection is an important strategy for promoting educational quality and standards in public secondary schools in Ekiti state if the inspectors comply fully with the principles of inspection. To be able to achieve the desired goals, inspectors must be aware of all the principles that guide their job performance. This implies that there is a need for formal preparation and orientation of intending inspectors and adequate in-service training and re-training of the inspectors already on the job to ensure adequate knowledge of the principles guiding inspection. Thus, organizing more and regular intensive in-service training/seminars/workshops for inspectors in the inspectorate services of the ministry of education is capable of promoting inspectors' compliance with inspection principles. This will enable them to keep pace with the challenges and continuous changes in the education sector. This agrees with the findings of Ogunu (2002) and Ochuba (2010) that inadequate number of inspectors and nonattendance at in-service training and workshops have made the quality of instruction given to students in schools' decline progressively. The findings from this study have implications for stakeholders in the education industry especially the inspectors of education in the ministry, the principals, teachers, policy makers as well as the government to guide their decisions on educational development in the state.

Results from analyses of in-depth interview however, showed that inspectors always make necessary preparations before setting out for inspection exercises in the schools. However, the inspectors are usually faced with different challenges in carrying out their duties. These challenges include inadequate number of inspectors, inadequate facilities and inadequate finance from the inspectorate department while in the schools, lateness to school by teachers and students pose great challenges. It is important to note that most of the challenges in the inspectorate division are usually noted and passed to the Ministry of Education for assistance while students and teachers that come late to school are usually warned to desist from such habits. Also, most principals make use of their vice-principals to supervise teachers while some do occasional checks by themselves. The inspection exercise is generally a good approach to monitoring and supervising teachers' delivery of instructions in the public secondary schools. It is therefore recommended that continuous inspection of schools is imperative to promote educational development in Ekiti state. Theinspectorate services shouldtherefore organize more intensive training, seminars and workshops for inspectors' capacity building in order to promote their compliance with inspection principles. The Ministry of Education in Ekiti state should intensify its effort in conducting short and operational inspection visits to schools and other types of inspection visits such as "on-thespot" and "general" inspection in a bid to monitor and assess teachers' instructional activities. 


\section{References}

Abolade, J. 0. (2007). Whole school education. Paper presented at the induction and re-orientation workshop for Federal and state inspectors of education, Akure.

Adelabu, M. A. (2003). Motivation and communication strategies and their application in primary school supervision, in Ajayi, A. and Olayisade A. (eds.) Education quality assurance: Ekiti State SPEB initiative, Gabesther educational publishing company, Ibadan.

Aghenta, J. A. (2006). Human resource development and planning in Nigeria. Second Faculty of Education distinguished lecture series, University of Benin, Benin City, Nigeria.

Alade, M. (2008). Current issues in educational reforms: Ekiti State experience. In Contemporary Issues in Educational Management, Ibadan: Macmillan Nigeria Publishers Limited.

Asika, N. (1991). Research methodology in the behavioural sciences, Longman, Nigeria.

Bamisaye, E. A. (1998). Job satisfaction among secondary school teachers in Osun state. Nigerian Journal of Educational Administration, 56, 239-250

Dean, J. (1995). What teachers and head teachers think about inspection? Cambridge Journal of Education, 25(1), 45-52.

FME. (2006). National conference on the continual decline in the standards of education in schools, Vol. 1\&II, Federal Ministry of Education Lagos: NERDC Press.

Gleim, J. A. \& Gleim, R. R. (2003). Cronbach Alpha and Spearman-Brown coefficient of reliability explanations. Paper presented at the Midwest research-to-practice conference in adult, continuing, and community education, The Ohio State University, Columbus, OH, October 8-10, 2003.

Gujarati, D. N. (2006). Basic econometrics, $4^{\text {th }}$ edition, Tata McGraw-Hill Publishing Company Limited, New York.

Kpolovie, P. J., Ololube, N. P. \& Ekwebelem, A. B. I. (2011).Appraising the performance of secondary school students on the WAEC and NECO SSCE from 2004 to 2006. International Journal of Scientific Research in Education, 4(2), 105-114.

Likert, R. (1932). A technique for the measurement of attitudes. Archives of Psychology, 140, 55

Maranga, J. S. (1986). Analysis of school inspectors' perception of teacher-inspector relationship. Kenya Journal of Education, 3(1), 30-52.

Marshall, C. (2008). Raising educational standards for children with additional Needs. British Journal of Special Education, 35(2), 69-77.

Nworgu, B. G. (2006). Educational research basic issues and methodology. Ibadan, Nigeria: Wisdom Publishers.

Obilade, S. O. (1992). Supervisory behaviour as perceived by secondary school teachers in Nigeria. School Leadership and Management, 12(2), 237-243.

Ochuba, V. O. (2010). Improving the quality of education in Nigeria through effective inspection of schools. Education.FindArticles.com. Accessed: 18 February, 2010.

Ogunu, M. A. (2002). The role of school inspectors in the implementation of the universal basic education (UBE) in Nigeria. In Ajayi, T. et al., (Eds.). Planning and administration of universal basic education (UBE) in Nigeria, Ijebu-Ode: Lucky Odoni (Nigeria) enterprises.

Onyidoh, H. (2007). The decline of the education system in Nigeria. Online education. Available: Helium http:/ www. Helium.Com.

Wilcox, B. (2000). Making school inspection visits more effective: the English experience. International Institute for Educational Planning/UNESCO, Paris. 